\title{
MANAGEMENT AND INTRINSIC HURDLES IN THE DEVELOPMENT PROCESS OF INTEGRATED COMMUNICATION BETWEEN SERVICE PROVIDERS AND CONSUMERS
}

\author{
Aurelija Ulbinaite ${ }^{1}$, Grazina Zdanovic ${ }^{2}$
}

\author{
Business Department, Faculty of Economics, Vilnius University, Saulètekio al. 9, Vilnius, Lithuania \\ E-mails: 'aurelija.ulbinaite@ef.vu.lt (corresponding author); ${ }^{2}$ grazina1972@gmail.com
}

\begin{abstract}
Integrated communication is an effective strategic tool that enables creating and maintaining tight dialogue and cooperation between service providers and consumers, managing communication chaos, information flow, matching consumers' needs. Its successful application requires reorganizing the communication processes, implementing their strategic changes, introducing new attitudes towards work and new culture, striving for overall synergy. Under such changes, this article aims at identifying the hurdles hindering the effective integration of smooth service providers and consumers' communication. Testing hypotheses based on a survey demonstrates that hurdles reflecting employees' competences, integrated communication development resources and result evaluation are more frequent in the stage of communication channel integration than in the functional one.
\end{abstract}

Keywords: integrated communication, hurdles, strategic management, service providers, consumers.

JEL Classification: D83; L1; M1.

\section{Introduction}

The introduction of integrated communication between service providers and consumers is deemed to be a significant research development phase (Kitchen, Schultz 2003). The ever happening market changes and the increasing impact of actions of uncontrollable environment have become an inseparable part of companies' activities. In such a situation, the framework of different paradigms and research changes and new attitudes towards traditional concepts arise. For decades, one of the keytasks has been recognition of consumer needs and understanding consumer behaviour, as well as activity planning, implementation and control which could in the most optimal, i.e. shortest way reach goals of both communication and sales (Proctor, Kitchen 2002). Integration has also become a main object in the communication sphere and research. In 1980, the heads of the leading advertisement agencies started to speak about the impact of integration on communicational effectiveness; later on, the concept started to be analysed by the researchers in the domains of marketing (Schultz 1996), public relations (Wightman 1999) and corporate identity (Cornelissen, Lock 2001).

Integration as a concept defines the connection of single parts and elements into the whole (Tarptautiniu žodžių žodynas 2001). The manifestations of this process can be found in various management spheres and processes: integration of single functions (finance, personnel, production, marketing), integration of single departments (sales, product development, planning), and integration of single marketing elements (price, product, promotion and place). Often, the need for such an integration is determined by optimal results of activities, i.e. a more proper information management, more effective communication, bigger synergetic effect that has an impact on financial results.

According to De Pelsmacker et al. (2004), the need for integration has been increased not only by the reduction of effectiveness of mass advertisement and technological evolution, but also by certain internal changes of marketing environment as of itself: i.e., by reduction of consumer loyalty, fragmentary media, communicational erudition of consumers, and entrenchment of the relationship marketing paradigm. The uniformity of primary quality and visual dimensions of products and services allows doing an assumption that communicational means and their proper usage has become one of the most important tools for creating company's competitive advantage (Žemaitiene 2009).

\section{Conceptual views on integrated communica- tion between service providers and consumers}

\subsection{Traditional vs. integrated communication}

An integrated communication between service providers and consumers is more focused on keeping long-term relationships with consumers and is more individualised than a traditional one. It does 
Table 1. Comparison of traditional and integrated communication between service providers and consumers (Source: compiled by the authors, according to Žemaitienè 2009)

\begin{tabular}{l|l|l|l}
\hline \multicolumn{1}{c|}{ Authors } & \multicolumn{1}{c|}{ Criteria } & \multicolumn{1}{c}{$\begin{array}{c}\text { Traditional } \\
\text { communication }\end{array}$} & \multicolumn{1}{c}{ Integrated communication } \\
\hline De Pelsmacker et al. 2004 & Focus & Short-term result & $\begin{array}{l}\text { Creating and maintaining } \\
\text { consumer relationship }\end{array}$ \\
\hline Pickton 2004 & Extent & Mass communication & Individual communication \\
\hline De Pelsmacker et al. 2004; Fill 2002 & Type & Monolog & Dialogue \\
\hline Gayeski, Woodward 1996 & Initiative maker & Service provider & Service consumer \\
\hline Calder 2007 & $\begin{array}{l}\text { Means of obtain- } \\
\text { ing results }\end{array}$ & Constant repeating & $\begin{array}{l}\text { Efficiency and satisfying } \\
\text { consumer needs }\end{array}$ \\
\hline Calder 2007 & Interaction & Direct selling & Direct consulting \\
\hline
\end{tabular}

not have a negative appearance that is common for a traditional mass communication style (De Pelsmacker et al. 2004).

The main differences in patterns between traditional and integrated communication that happens between service providers and consumers are provided in Table 1 .

Taking into consideration the main changes in the market and in comparison with the changes in communication, one can state that the most relevant challenge for service providers is the changes of power concentration in the market that is more and more consumer-focused (Calder 2007). Having variety of choices and limited time resources, consumers have an increasing impact in the decisionmaking process and thus highly lift the requirements for service providers who have to adjust to ever increasing consumers' needs. De Pelsmacker et al. (2004) describe such a situation as a market oriented marketing entrenchment where not only communication, but also other activity solutions have to be at maximum consumer-oriented. In other words, the nature and principles of communication is not a prerogative of service consumers, but their reaction to conditions that are dictated by consumers. It can be noted that this change, even if it is tangible in an environment of service providers, it is not practically entrenched in companies themselves and is limitedly perceived by researchers that analyse communication process (Schultz 2003).

Consumer multidimensional dependence problem is not a less important challenge; a company as a unite always communicates with different target groups: consumers, shareholders, employees and suppliers (Bickerton 2000). A contemporary consumer can represent, and at the same time be dependent on, several completely different groups (De Pelsmacker et al. 2004; Pickton, Hartley 1998). An employee of a company can at the same time be both shareholder, consumer and opinion leader. Taking into account the fact that communication with each of these groups is done using different communicational channels and means, companies must ensure that information that is given to consumer by different means would be clear and sequential, would reflect communicational messages, and would not have contradicting contents (De Pelsmacker et al. 2004). So an integration between service providers and consumers is treated to be a relevant process that can manage communicational noise and accurately provide needed information to consumers.

\subsection{Development of integrated communication under impact of external changes}

The main environmental changes that determine the manifestation of factors of integrated communication between service providers and consumers are related to macroeconomic environmental factors and new challenges in economic, social and technologic environments (Žemaitienè 2009) (see Table 2). In other words, these changes determine specific shifts that are related to internal marketing environment and its changes, as well as new objectives for companies.

Integrated communication is a way that enables helping companies to properly react to changes of surrounding environment. Researchers define integrated communication between service providers and consumers differently and most often by definitions that contradict to each other (Gurau 2008; Kliatchko 2005). The classical definition is considered to be the one suggested by the American Marketing Association in 1989 which states that integrated communication between service providers and consumers is such a communication planning concept by which an action plan should be created, the elements of which (advertisement, 
sale promotion, and public relations) would communicate a clear, consistent, and steady message with a maximal possible impact on targeted markets (Christensen et al. 2008; Duncan, Moriarty 1998). It additionally suggested that integrated communication requires different communication channel coordination actions to form and execute a unified communicational message. Communicational functions must be planned, realised and evaluated as a unified system. A group of researchers (Duncan 2002; Fill 2002) highlight the role of establishment of relationship with consumers and maintaining this relationship in the process of integrated communication. This implies that communication by its nature should be not onesided, but instead planned and carried out by means of a dialogue. It should not only be a trial to transfer a specific message to consumers, but it should also grasp their reactions, evaluate whether the message has been perceived properly, or not.

Table 2. Environmental changes that might have caused manifestation of the integrated communication (Source: compiled by the authors, according to Žemaitienè 2009)

\begin{tabular}{l|l}
\hline \multicolumn{1}{c|}{ Authors } & \multicolumn{1}{c}{ Environmental changes } \\
\hline Schultz, Kitchen 2000 & $\begin{array}{l}\text { Fragmentary nature of } \\
\text { traditional mass media }\end{array}$ \\
\hline $\begin{array}{l}\text { De Pelsmacker } \text { et al. } \\
\text { 1993; Duncan, Everett }\end{array}$ & $\begin{array}{l}\text { Fragmentarity and over- } \\
\text { lapping of audience }\end{array}$ \\
\hline Hutton 1996 & $\begin{array}{l}\text { Fast internet and fast dis- } \\
\text { semination of new tech- } \\
\text { nologies }\end{array}$ \\
\hline Balmer 2001 & $\begin{array}{l}\text { A shortening of product } \\
\text { life cycle }\end{array}$ \\
\hline Kitchen, Schultz 1999 & $\begin{array}{l}\text { Globalisation and appear- } \\
\text { ance of free economic } \\
\text { zones }\end{array}$ \\
\hline $\begin{array}{l}\text { Schultz 2003; Calder } \\
\text { Displacement of power } \\
\text { centre towards consumer }\end{array}$ \\
\hline Moriarty 1994 & Intensifying competition \\
\hline Kitchen et al. 2004 & $\begin{array}{l}\text { Fast entrenchment of rela- } \\
\text { tionship paradigm }\end{array}$ \\
\hline Fam 2001; Gurau 2008 & $\begin{array}{l}\text { A need for maintain con- } \\
\text { sumer loyalty by all means }\end{array}$ \\
\hline Keller 2001 & $\begin{array}{l}\text { A will to increased brand } \\
\text { value and its capital }\end{array}$ \\
\hline
\end{tabular}

The other sources (Calder 2007) highlight that integrated communication is a consumer-focused method based on data analysis, the goal of which is to create positive associations that, from the viewpoint of an organization, would definitely impact personal motivation, attitude and behaviour. Inte- grated communication starts from a representative of consumers or targeted groups and it is reflected by all forms of contacts in attainment of synergy, change and making impact on consumer behaviour and strengthening mutual relationships (Kitchen et al. 2004; Žemaitienè 2009).

Kitchen et al. (2004) state that integrated communication out of a mean of informational transfer becomes to an essential strategic tool for creating and maintaining relations with consumers. Schultz, Kitchen (2000) define integrated communication as a strategic management process that is used to plan, develop, execute and evaluate matching and convincing communication programs that are in a long-term perspective focused on consumers, clients, as well as internal and external targeted groups (Kitchen et al. 2004). It is highlighted that integrated communication should not be perceived only as a simple process of communication planning, but should also be evaluated as an important strategic management tool. This attitude is supported by Fill (2002), who considers the integrated communication as a management process that directly impacts and strengthens a brand's value.

\subsection{Pros and cons of integrated communication}

After reviewing the scientific literature, the main particularities of integrated communication can be identified (see Table 3).

In the opinion of Kitchen, Shultz (1999), an integrated communication is still in the grip of a kind of conceptual framework; since there exist many different ideas about and definitions of conception itself, the process and its implementation. Even though many researchers have been working on the clarification of this conception (Duncan 2002; Fill 2002; Kitchen, Schultz 1999; Wightman 1999; Kliatchko 2005), the research community is still in the search for a common agreement on what integrated communication is concerned with. According to Žemaitienè (2009), such a situation becomes a rather threat-full from a practical point of view when companies in reality differently perceive integrated communication, agreeing that they apply it differently, thus in this way some diffusion is created to define the concept. This becomes one of the main arguments of critics of integrated communication, who, referring to the fact that there is no a clear, agreeable and unified definition of integrated communication, consider this concept as an elementary fashion of management (Cornelissen, Lock 2000). Thus, a contribution of researchers and their future work about it is essentially important for developing, extending and 
clarifying the conception of integrated communication. The integrated communication has become a dominated paradigm that clearly defines the main principles of active communication (Kitchen et al. 2004).

Table 3. The conceptual particularities of integrated communication (Source: compiled by the authors, according to Žemaitienè 2009)

\begin{tabular}{l|l}
\hline \multicolumn{1}{c|}{ Authors } & \multicolumn{1}{c}{ Highlights } \\
\hline $\begin{array}{l}\text { Schultz 1996; Hartley, } \\
\text { Pickton 1999 }\end{array}$ & $\begin{array}{l}\text { Impact on consumer be- } \\
\text { haviour by targeted com- } \\
\text { munication means }\end{array}$ \\
\hline $\begin{array}{l}\text { Duncan 2002; } \\
\text { Kliatchko 2005 }\end{array}$ & $\begin{array}{l}\text { Implementation of com- } \\
\text { munication actions that } \\
\text { are at maximum consum- } \\
\text { er-focused }\end{array}$ \\
\hline Schultz 2003; Kitchen, & $\begin{array}{l}\text { Usage of any contact with } \\
\text { targeted auditorium for } \\
\text { creating synergy and dia- } \\
\text { logue 2002; De }\end{array}$ \\
Pelsmacker et al. 2004 & $\begin{array}{l}\text { Strengthening relations } \\
\text { with targeted groups }\end{array}$ \\
\hline $\begin{array}{l}\text { Schultz 2003; Kitchen, } \\
\text { Eagle 2002; Fill 2002; }\end{array}$ & \\
\hline
\end{tabular}

The work behind this paper is conducted by accepting the relevance of the strategy of integrated communication between service providers and consumers and highlighting the relevance of a max focus on consumers. This attitude more consistently explains the definition of integrated communication itself, its main principles and its process. When analysing the development of integrated communication, it is important to encounter a wider as possible spectrum of it.

The definition provided by Kitchen et al. (2004) fits the ideological principles of integrated communication, by which it is considered as a tool of strategic management that is used for planning, development, implementation and evaluation of adjusted and convincing communication programs that are directed to consumers, clients and other defined internal and external groups in a long-term perspective. In order to properly evaluate the conceptual meaning of integrated communication, it is needed to perceive its main conceptual advantages and disadvantages.

Integration advantages are related to a better organisation of a company's activity, an increased cooperation in different groups, a higher aspiration for results, a better usage of organizational costs, a bigger communicational impact on targeted groups (Schultz 1996). Implementation of the integrated communication decreases costs for advertisement, provides bigger competitive advantage (Duncan,
Everett 1993; Phelps, Johnson 1996), and maintains the sequence of communication messages. It also helps to effectively carry out the activity, to better recognize the needs of consumers and their behaviour prototypes (Duncan 2002), allows creating higher consumer loyalty, maintaining relations with them (Schultz 2003). Successful implementation of integrated communication allows reaching effectively the defined goals of communication and makes a bigger impact on sales. Integrated communication can purposefully direct communication from the consumer point of view and to make it more powerful and convincing from a service provider view point (Kitchen et al. 2004).

Integrated communication has its drawbacks as well. Earlier service providers could react to fast changing macro-economic environment by simply changing or correcting communication elements or the combination of elements of marketing complex by using integrated communication, what becomes more and more difficult under fast changing macro-economic environment. Schultz (2003) notes that giving too much attention to integration limits the abilities of service providers to flexibly and quickly react to actions of competitors or other strategic groups of service providers in a market. If earlier it was possible to react to challenges in a market by integrating one of communication functions, there is a need for a complex decision that is rather time-consuming under changing environment. In order to reach consumers by means of a consistent and uniform communication message, service providers do forget competitors and get trapped in. Integration should not become a precedent of bureaucracy or a framework of a strong arm politics in companies (Žemaitienè 2009).

The advantages and drawbacks of integrated communication are provided in Table 4.

Table 4. Advantages and disadvantages of integrated communication (Source: compiled by the authors, according to Žemaitienè 2009)

\begin{tabular}{l|l|l}
\hline \multicolumn{1}{c|}{ Authors } & \multicolumn{1}{c}{ Advantages } & \multicolumn{1}{c}{ Disadvantages } \\
\hline $\begin{array}{l}\text { Fill 2002; } \\
\text { Proctor, } \\
\text { Kitchen 2002 }\end{array}$ & $\begin{array}{l}\text { Higher commu- } \\
\text { nicational } \\
\text { impact }\end{array}$ & $\begin{array}{l}\text { Slow decisions, } \\
\text { loss of flexibil- } \\
\text { ity }\end{array}$ \\
\hline $\begin{array}{l}\text { Phelps, John- } \\
\text { son 1996 }\end{array}$ & $\begin{array}{l}\text { More effective } \\
\text { creative ideas }\end{array}$ & $\begin{array}{l}\text { More compli- } \\
\text { cated evaluation } \\
\text { and measuring }\end{array}$ \\
\hline Smith 1998 & $\begin{array}{l}\text { More clear and } \\
\text { consistent com- } \\
\text { munication }\end{array}$ & $\begin{array}{l}\text { Time- } \\
\text { consuming }\end{array}$ \\
\hline $\begin{array}{l}\text { Wightman } \\
\text { 1999; Kitchen } \\
\text { et al. } 2004\end{array}$ & $\begin{array}{l}\text { Higher invest- } \\
\text { ment return }\end{array}$ & $\begin{array}{l}\text { Higher financial } \\
\text { investment }\end{array}$ \\
\hline
\end{tabular}


According to Žemaitienè (2009), when analysing the conception of integrated communication, it is also essential to evaluate a wider communicational context, as it indicates how integrated communication is evaluated and concerned in the context of other communication forms, reflects its complexity and at the same time helps to distinguish and define the role of integrated communication and its relations with targeted groups.

\subsection{The process of integrated communication and its stages}

In the scientific literature, an integrated communication between service providers and consumers is most often analysed as a conception or as a process. In the former case, it is defined as a way of thinking or an attitude towards communication planning. When evaluating the integrated communication from a process point of view, its specific implementation stages are analysed, i.e. creation of databases, management of information about consumers, planning and dissemination of communication messages, evaluation of the results and effectiveness (Kliatchko 2005).

The process of integrated communication starts with the stage of planning and finishes with evaluation of the results and effectiveness in a long-term perspective (Kliatchko 2005). Target groups that are important for organizations are identified by using information and records of databases. The accuracy and insight of this process and the selection of profitable segments and markets guarantee the huge part of the integrated communication program success in a long-term perspective. When the target markets are clear, the channels of possible communicational connection are analysed. They guarantee effective reception of the message that is sent at a maximal level and allow communicating targeted communicational programs. Further, the effectiveness of the conducted actions is evaluated from the viewpoint of dedicated funds and factual financial return (Kliatchko 2005). When discussing about the development process of integrated communication between service providers and consumers, researchers, in their early papers, identify it with implementation of horizontal coordination mechanisms, creation of inter-functional work-groups (Schultz, Barnes 1995; Duncan, Moriarty 1998) and concentration of all communication disciplines (advertisements, sales promotion, public relations) in one subdivision.

Later on, it has been discussed that development of integrated communication encompasses more than just implementation of structures of horizontal communication coordination and control; it happens based on a vertical principle. Duncan, Caywood (1996) were one of the first ones to identify the main development stages of integrated communication between service providers and consumers that later on have been improved by other researchers of this field (Schultz 1996), the result of which was a model for developing integrated communication. The authors define the development process of integrated communication as having seven integration stages where each of them has equal weight (Duncan, Caywood 1996). They are as follows:

1. Perception of integrated communication.

2. Integration of image.

3. Functional integration.

4. Coordination integration.

5. Consumer-oriented integration.

6. Service provider-oriented integration.

7. Relationship management.

The first two stages highlight the need for applying the principles of integrated communication in an organization, brand and image integration aspects that are directly related with the third stage, which ensures smoothness and sequence of single communication functions (advertisement, public relations). Later on, a continuous integration of sales activities to communication spheres is going on and new contact points with the existing consumers are looked for (Žemaitienè 2009).

Schultz, Kitchen (2000), referring to their own conducted continuous intercultural empirical research results, corrected the process of development of integrated communication by distinguishing four levels in its development, as well as their priorities and sequence. Namely, the model of these researchers is held to be the main visualization of the development process of integrated communication between services providers and consumers and in the other sources it is as well called communication integration pyramid (Fam 2001; Bickerton 2000).

\subsection{Research hypotheses}

Schultz, Kitchen (2000), referring to their empirical research, conducted in different countries of the world, state that most of organizations are oriented to a tactical integration of communication factors, i.e. they focus on creation and dissemination of a smooth and constant communicational message.

When analysing barriers for development of integrated communication, it can be noted that researchers highlight different-nature-barriers. On 
the other hand, some common tendencies and agreements can be unfolded.

Most of researchers agree on the statement that attitudes and competences of employees generate a strong barrier for developing the integrated communication (Pickton 2004; Smith 1998; Moriarty 1994). Other authors highlight a lack of experience of specialists in different spheres of communication as well as ignorance of the main principles of integrated communication. A weak involvement of head managers in the processes of planning and execution of integrated communication together with their borne negative attitudes towards it are as well concerned to be an obstacle that limits development of integrated communication. Taking this into consideration, the first research hypothesis in our work is formulated as follows:

H1: The manifestations of the hurdles (barriers) that are caused by the attitudes of chief executives of companies are more frequent in the stage of communication channel integration than in the stage of functional integration.

Integrated communication has to be a part of strategical planning and management of a company, so its payback is evaluated. Chief executives have to reject ordinary measures of activity planning and to move a part of their responsibilities on the shoulders of competent marketing experts. However, the attitudes of the chief executives towards doing this are sceptical and they tend to withstand this.

$\mathrm{H} 2$ : The manifestations of the hurdles (barriers) that are caused by the limits of the competencies of the specialists are more frequent in the stage of communication channel integration than in the stage of functional integration.

In their works, Smith (1998), Duncan, Everett (1993), Kitchen highlight that, in the process of development of integrated communication, conflicts of interests are rather common; both employees and heads of departments are inclined to protect their interests, to defend their zones of impact. In such cases, there is a lack of proper cooperation, the exchange of information does not occur, as well as forming united communication attitudes is not possible. If the actions carried out in a company are not coordinated with each other, this often leads to conflicts of interests, disagreements and extreme differences in opinions. A proper cooperation in the company is of key-relevance for its all functional areas. From the viewpoint of developing integrated communication between service providers and consumers, it is particularly relevant in the first stage of development process, where there is a need for active combination and coordination of all communication actions. Since up to now, traditionally, all these functions have been working independently, the change requires not only creating new forms, processes and rules but also one's proper mind and positivity. Thus, the hypothesis is formulated as follows:

H3: The manifestations of the hurdles (barriers) that are caused by the inter-cooperation within the company are more frequent in the stage of communication channel integration than in the stage of functional integration.

Most of authors that research integrated communication (among others Fam 2001; Pickton 2004) give the stronger weight of barrier-based cases of development of integrated communication between service providers and consumers to improper organisational structures. The structures must be improved so that they adapt the needs for integrating communication between service providers and consumers. A lack of proper organisational structures, together with a lack of specific tools for measuring effectiveness and results, tend to be the weakest point in a company. Formal structures of a company that are based on a vertical communication and hierarchical responsibility are rather inflexible for coordination of communication of actions at a tactical level when departments are in need to actively communicate and cooperate with each other. It leads to a hypothesis that is formulated as follows:

H4: The manifestations of the hurdles (barriers) that are caused by the organisational structure of a company are more frequent in the stage of communication channel integration than in the stage of functional integration.

When evaluating resources that are needed for developing the integrated communication, amongst the most often distinguished ones there is a lack of time (Smith 1998), of finances (Schultz 1996) and of human resources (De Pelsmacker et al. 2004). Financial resources are the most highlighted ones in this group; they are needed for creation of databases and integration of information technologies into consumer behaviour evaluation systems. As the most prominent researchers of integrated communication Schultz, Kitchen (2000) state, in the stage of technological integration, a solid need for additional finances increases scepticism of heads of companies in the value generated by the integrated communication and, thus, impedes its future diffusion. With this statement the following hypothesis is formulated:

H5: The manifestations of the hurdles (barriers) that are caused by the integrated communica- 
tion development resources are more frequent in the stage of communication channel integration than in the stage of functional integration.

Evaluation of the results of integrated communication and measuring of its effectiveness can be concerned as one of the most discussable integrated communication development problems. Even though the authors (Kitchen et al. 2004; Fam 2001; Pickton 2004) state that most companies try to evaluate effectiveness of programs that are carried out to ensure integrated communication, there are no united, explicit and methodology-based tools which would allow properly defining the effect of communication integration as well as specifically of financial communication integration, where communication in question between service providers and consumers is in evaluation. This group of obstacles is of the same significance in all stages of the process of integrated communication development. It can be noted that employees of companies most actively discuss about the tools of evaluating effectiveness of integrated communication when changing extent of communication and when involving previously unused forms and methods of integrated communication into the spectrum of communication channels and tools. Referring to this, the hypothesis is formulated as follows:

H6: The manifestations of the hurdles (barriers) that are caused by the evaluation of integrated communication results are more frequent in the stage of communication channel integration than in the stage of functional integration.

Meanwhile, interrelations with communication agencies are not extensively discussed in the analysed research works. Kitchen et al. (2004) distinguish the problems of communication interrelations between agencies themselves and their relations to the clients (companies); functional specialisation (in this case, it is a hired company that provides all-in-one services) as a barrier of integrated communication is mentioned in the works of Eagle, Kitchen (2000), Kitchen, Schultz (1998). On the other hand, communication agencies that act in both national and foreign markets have a very different baggage of experience; this may lead to inadequate services of communication agencies. Clients may not recognise them as strategical partners because of their too big orientation to decision fulfilment at a tactical level. The competencies of agencies are especially significant when a company extends communication extents, is in search of new communication forms with consumers and is in need to disseminate information through different channels, doing this using different tools and in different forms. Referring to this, the hypothesis as follows is formulated:

H7: The manifestations of the hurdles (barriers) that are caused by the interrelations with the external companies are more frequent in the stage of communication channel integration than in the stage of functional integration.

\section{Research methodology}

The goal of the research is to identify the strength of the manifestation of hurdles between service providers and consumers in the development process of integrated communication.

To test the formulated research hypotheses, the following methods and techniques are applied:

- Barrier manifestation frequency is determined by using the mean of the evaluations of the research participants - experts.

- Barrier frequency is compared in different stages, using Mann-Whitney test for comparing the statistical significance of the mean of two or more independent samples.

\section{Research results}

For testing the raised research hypotheses, firstly the means of manifestations of hurdles are calculated in relation to different stages of integrated communication development (see Table 5).

For measuring the answers of research participants a 10-point Likert scale is used. The smaller the value, the stronger the manifestation of hurdle in the process of integrated communication development.

The data reveal that the manifestation of hurdles is statistically significantly more frequent in the stage of communication channel integration than in the stage of functional communication for the three groups of hurdles, i.e. competencies of specialists who work in a company, evaluation of the results of integrated communication and integrated communication development resources $(p$ values are $0,048,0,039$ and 0,030 , respectively). With this, the research hypotheses $\mathrm{H} 2, \mathrm{H} 5$ and $\mathrm{H} 6$ are confirmed, whereas $\mathrm{H} 1, \mathrm{H} 3, \mathrm{H} 4$ and $\mathrm{H} 7$ are rejected.

The research data indicate that in the stages of both functional integration and communication channel integration, the evaluation of the results of integrated communication $(4,41$ and 2,82 , respectively) is the most critical obstacle (see Table 5). The tendencies of the development of integrated communication directly correlate with the existing theoretical views. In the thematic of eliminating 
Table 5. Estimates of the frequency of manifestation of barriers and their statistical significance in the stages of functional integration and communication channel integration that result from the research survey of experts (Source: compiled by the authors, according to Žemaitienè 2009)

\begin{tabular}{|c|c|c|c|}
\hline \multirow[t]{2}{*}{ Groups of barriers } & $\begin{array}{l}\text { Stage of functional } \\
\text { integration }\end{array}$ & $\begin{array}{c}\text { Stage of communication } \\
\text { channel integration }\end{array}$ & \multirow{2}{*}{$\begin{array}{c}p \text {-value } \\
\text { (Mann- } \\
\text { Whitney) }\end{array}$} \\
\hline & \multicolumn{2}{|c|}{ Mean } & \\
\hline Attitudes of a company's chief executives & 6,40 & 5,86 & 0,130 \\
\hline Competences of specialists who work in a company & 6,86 & 5,87 & 0,048 \\
\hline Cooperation in a company & 7,01 & 5,56 & 0,061 \\
\hline Organizational structure & 6,39 & 4,85 & 0,065 \\
\hline Evaluation of the results of integrated communication & 4,41 & 2,82 & 0,039 \\
\hline Integrated communication development resources & 7,11 & 5,48 & 0,030 \\
\hline $\begin{array}{l}\text { A company's communication with external compa- } \\
\text { nies (agencies) }\end{array}$ & 6,61 & 5,51 & 0,232 \\
\hline
\end{tabular}

hurdles, significant attention is given to the problems of evaluating results and effectiveness of integrated communication, when searching for commonly accepted evaluation systems that are methodically proven (Cornelissen, Lock 2000; Kitchen et al. 2004).

\section{Conclusions}

The prominence, frequency and stage of hurdles during the development process of integral communication were identified by testing hypotheses in relation to a questionnaire-based survey used as the data collection method. By evaluating means of the identified communicational hurdles $(p<0.05)$, this study has demonstrated that manifestations of a) hurdles of employed specialists' competence (among others, knowledge), b) hurdles of integrated communication development resources (human resources and strategy), and c) hurdles of integrated communication result evaluation - are all more frequent in the stage of communication channel integration than in the functional communication integration. The conducted study has identified that the development of integrated communication is, to a huge extent, limited by the lack of integrated communication (result) evaluation systems, whereas a weaker impact is due to the hurdles that are caused by integrated communication development resources and employees' competence.

Possible future work could investigate the integrated communication theoretical models and their real-life application to better understand the salient features that are responsible for the rejected hypotheses and to derive possible corrective actions.

\section{References}

Balmer, J. M. T. 2001. Corporate identity, corporate branding and corporate marketing: seeing through the fog, European Journal of Marketing 35(3/4): 248-291.

http://dx.doi.org/10.1108/03090560110694763

Bickerton, D. 2000. Corporate reputation versus corporate branding: the realist debate, Corporate Communications: An International Journal 5(1): 42-48.

Calder, B. J. 2007. An illustration of integrated marketing at Kellogg on integrated marketing, Northwestern University. John Wiley \& Sons, Inc.

Christensen, L. T.; Firat, A. F.; Torp, S. 2008. The organization of integrated communications: towards flexible integration, European Journal of Marketing 42(3/4): 423-452.

http://dx.doi.org/10.1108/03090560810853002

Cornelissen, J. P.; Lock, A. R. 2000. Theoretical concept or management fashion? Examining the significance of integrated marketing communications, Journal of Advertising Research 1: 7-15. http://dx.doi.org/10.2501/JAR-40-5-7-15

Cornelissen, J. P.; Lock, A. R. 2001. The appeal of integration: managing communications in modern organizations, Marketing Intelligence and Planning 19(6): 425-431.

http://dx.doi.org/10.1108/EUM0000000006110

De Pelsmacker, P.; Geuens, M.; Van Den Bergh, J. 2004. Marketing communications: a European perspective. Edinburgh: Person Education Limited.

Duncan, T. 2002. From integrated marketing communications to integrated communication, Corporate Communications: An International Journal 6(4): 213-233.

Duncan, T. R.; Everett, S. E. 1993. Client perceptions of integrated marketing communications, Journal of Advertising Research 33(3): 30-39.

Duncan, T.; Caywood, C. 1996. The concept, process and evolution of integrated marketing communications, in J. Thomson, E. Moore, E. (Eds.). Integrat- 
ed Communication: synergy of persuasive voices. Mahwah, NJ: Lawrence Erlbaum Associates.

Duncan, T.; Moriarty, S. E. 1998. A communication based marketing model for managing relationships, Journal of Marketing 62(2): 1-13. http://dx.doi.org/10.2307/1252157

Eagle, L.; Kitchen, P. J. 2000. Integrated marketing communications, brand communications and corporate cultures, European Journal of Marketing 34(5/6): 667-686. http://dx.doi.org/10.1108/03090560010321983

Fam, K. S. 2001. Differing views and use of integrated marketing communications - findings form a survey of New Zealand small businesses, Journal of Small Businesses and Enterprise Development 8(3): 205-214. http://dx.doi.org/10.1108/EUM0000000006821

Fill, Ch. 2002. Marketing communications: contexts, strategies and applications. $3^{\text {rd }}$ ed. Harlow: Pearson Education Lt.

Gayeski, D. M.; Woodward, B. E. 1996. Integrated communication: from theory to performance [online], [cited 26 April 2016]. Available from Internet: http://www.dgayeski.com/omninteg.html

Gurau, C. 2008. Integrated online marketing communication: implementation and management, Journal of Communication Management 12(2): 169-184. http://dx.doi.org/10.1108/13632540810881974

Hartley, B.; Pickton, D. 1999. Integrated marketing communications requires a new way of thinking, Journal of Marketing Communications 5(2): 97106. http://dx.doi.org/10.1080/135272699345699

Hutton, J. G. 1999. Integrated relationship-marketing communications: a key opportunity for integrated marketing communications, Journal of Marketing Communications 2(3): 191-199.

http://dx.doi.org/10.1080/135272696346141

Keller, K. L. 2001. Building customer-based brand equity: a blueprint for creating strong brands, Marketing Management 10(July/August): 15-19.

Kitchen, P. J.; Brignell, J.; Li, T.; Spicket, G. J. 2004. The emergence of integrated marketing communications: a theoretical perspective, Journal of $\mathrm{Ad}$ vertising Research 1: 19-30. http://dx.doi.org/10.1017/S0021849904040048

Kitchen, P. J.; Eagle, L. 2002. Towards a globalized communication strategy: perceptions from New Zealand, Marketing Intelligence and Planning 20/3: 174-184. http://dx.doi.org/10.1108/02634500210428030

Kitchen, P. J.; Schultz, D. E. 1998. Integrated marketing communications - a UK ad' agency perspective, Journal of Marketing Management 14(1): 465-485. http://dx.doi.org/10.1362/026725798784867806
Kitchen, P. J.; Schultz, D. E. 1999. A multi-country comparison of the drive for integrated marketing communications, Journal of Advertising Research 39(1): 21-38.

Kitchen, P. J.; Schultz, D. E. 2003. Integrated corporate and product brand communications, Journal of Current Issues and Research in Advertising 11(1): 66-86.

Kliatchko, J. G. 2005. Towards a new definition of integrated marketing communications, International Journal of Advertising 24 (1): 7-34.

Moriarty, S. E. 1994. Public relations and integrated marketing communications: the benefits of integrations, Public Relations Quarterly 39(3): 38-44.

Phelps, J.; Johnson, E. 1996. Entering the quagmire: examining the 'meaning' of integrated marketing communications, Journal of Marketing Communications 2(3): 159-172. http://dx.doi.org/10.1080/135272696346123

Pickton, D. 2004. Assessing integrated corporate communications, Handbook of Integrated Marketing communications, International Journal of Advertising 17: 447-457.

Pickton, D.; Hartley, B. 1998. Measuring integration: an assessment of the quality of integrated marketing communications, International Journal of Advertising 17: 447-457.

Proctor, T.; Kitchen, P. 2002. Communication in postmodern integrated marketing, Corporate Communications: An International Journal 7(3): 144-154.

Schultz, D. E. 1996. The inevitability of integrated communications, Journal of Business Research 37: 139-146. http://dx.doi.org/10.1016/S0148-2963(96)00063-X

Schultz, D. E. 2003. The evolving nature of integration, communications, Journal of Integrated Communications 23: 34-43.

Schultz, D. E.; Barnes, B. E. 1995. Integration, reputation and research, Journal of Integrated Communications 8: 19-26.

Schultz, D. E.; Kitchen, P. J. 2000. Communicating globally. New York and Hampshire: Hampshire.

Smith, J. B. 1998. Buyer-seller relationships: similarity, relationship management, and quality, Psychology \& Marketing 15(1): 3-21. http://dx.doi.org/10.1002/(SICI)15206793(199801)15:1<3::AID-MAR2>3.0.CO;2-I

Tarptautiniu žodžiu žodynas. 2001. Vilnius: Alma Littera.

Wightman, B. 1999. Integrated communications: organization and education, Public Relations Quarterly 44(2): 18-22.

Žemaitienè, R. 2009. Integruotosios marketingo komunikacijos vystymo barjerai organizacijoje: Doctoral thesis. ISM University of Management and Economics, Vilnius, Lithuania. 